\title{
Summary
}

The authors reported previously* that the heterocaryotic strains of Asp. oryzae produce generally larger and multinucleate (10 to 20 ) conidia while the original or parent homocaryons form smaller conidia which have only one to four nuclei. The present investigation has been carried out with the purpose to examine whether 17 strains of Asp. oryzae var. magnasporus, var. nov. SAKAGUCHI et YAMADA, ***: which were isolated from Koji of saké and soy sauce and described under the new varietal names, are also heterocaryons or not.

1) Those strains can be divided into tow distinct groups according to their abilities for segregation. The group A consists of 13 strains which are very liable to produce segregants and therefore are regarded as heterocaryons. Other four strains belonging to the group B remained constant through 4 or more successive generations of pedigree cultures as if they are homocaryotic, although their conidia are large in diameters and multinucleate.

2) The members of the group A generally give rise to several types of colonies upon subsequent monospore culture from 2 to 3 generations. Each strain is multple heterocaryon and is composed of $3 \sim 6$ factorial types. Most of the segregants are homocaryotic and form conidia with small diameters and $2 \sim 4$ nuclei. But several segregants which produce multinucleate and large conidia but remain constant without any segregation through many generations just as the strains of the group $B$.

3) The large conidial strains similar to the parent types (group A) can be produced by mix-cultures of the factorial types or the homo-type segregants.

4) As regards to the size and the caryotic conditions, two types, the smaller and $1 \sim 4$ nucleate and the larger and multinucleate types, may be distinguished among the constant and homocaryotic strains of Asp. oryzae. The new varietal name "magnasporus" proposed formerly by one of the authors, is therefore applicable to the latter strains of the group $B$.

5) It has occasionally observed that during the formations of coidia in the constant multinucleate strains (B group) more than two nuclei migrate at the same time from sterigmata into newly formed conidia. The phenomenon was reported by the present authors* only in the case of heterocaryotic strains.

* K. Sakagucht \& C. Isaitani : J. Agr. Chem. Soc. of Japan, 26, 85 (1952).

** K. Sakaguchi \& K. Yamada : J.Agr. Chem. Soc. of Japan, 20, 65, 141 (1944).

稻馬鹿苗病菌の生化学 (第31報) ヂベレリンの物理化学的定量法

北村 博, 任木諭介（東京大学農学部否芸化学教室）

昭和 29 告 2 月 16 日受理

The Biochemistry of Bakanae Fungus. Part 31. The Physico-Chemical

Determination of Gibberellin.

By Hiroshi Kitamura and Yusuke SumikI

(Department of Agricultural Chemistry, Faculty of Agriculture, University of Tokyo)

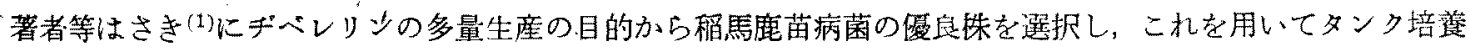

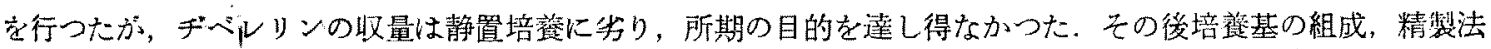
の改良を企画し，その為には侻来の生物試験による検定法より，上り忒速により正確に定量し得る物理化学的方 法を確立せんとし，I ベックマンの光電光度計による方法，II ポーラログラフ法を採用した。

I. デペレリンAを塩酸分解して得られるデベル酸(゙の紫外部に於计る特有な吸收曲線（Fig. 1) に着目し， 最大吸叹部に於ける吸光係数と濃度とが LAMBERT-BEER の法則に倓い比例関係を有することを知つたので， これを用いて培盖液中のヂベレリンAを定量せんとした。

、培盖液をエーテル或いは醋酸エチルにて抽出し，抽出物の一定量を塩酸分解し，或いは培養液そのまをを塩酸 分解して後エーテル抽出してヂベル酸を分離せしめ，常法に従いメタノールを溶媒として吸光俰数を测定した処 ギヘル酸の吸収曲線に比へて最大吸収部のピークがシャープでないために測定誤差が大きいと考え，エーテル抽 出物中の他の不純物除去を目的として該エーテル抽出物を稀アルコールにとかし，イオン卒換澍脂 $1 \mathrm{R} 4 \mathrm{~B}$ (分 析用）を用いたが不純物除去の目的を嫶し得なかつた，依つてヂベル酸については紫外部吸光係数を用いて定量 


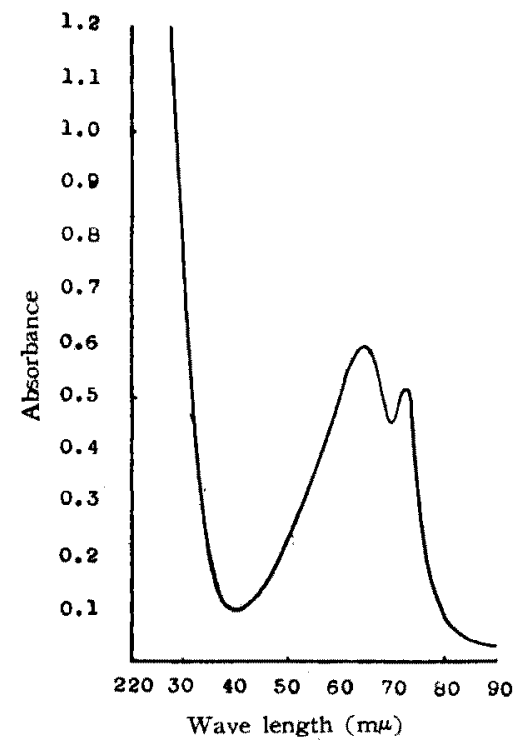

Fig. 1. Absorption Spectra of Crystalline Gibberic Acid ( $M / 500$ in Methanol)

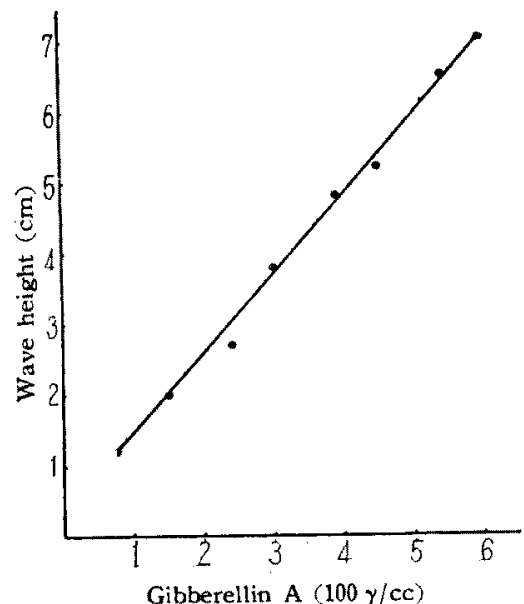
ration and the Wave-Height of Gibberellin A (Sensitivity $1 / 10$ )
Fig. 3. Standard Curve between the Concent-

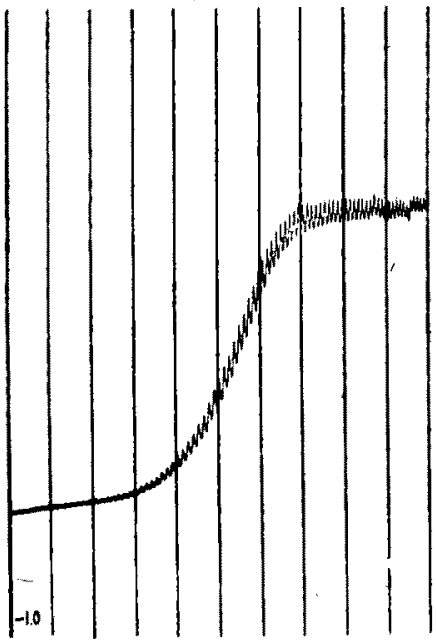

Fig. 2. Polargrams of $0.5 \times 10^{-3} M$ Gibberellin $\mathrm{A}$ in $0.04 \mathrm{~N}\left(\mathrm{CH}_{3}\right)_{4} \mathrm{NBr}$ aq. pH 3.3, Sensitivity $1 / 5$ $\pi_{1 / 2}=-1.56_{\text {volt }}$ (vs. S.C.E.)

は出来るが，ヂべレリンAの定量は不可能であつた。

II. ヂペレリンA (d.p. 240 ) を少量のアルコー ルに溶かし水溶液とし tetramethyl-ammoniumbromide を加光て電解液を作り $\mathrm{pH} 3.3$ でポーラロ グシフによつて測定した結果，1個の罩元波を示した (Fig. 2). この半波電位 $\pi_{1 / 2}$ （切点法の拡散電流の I/2に於ける筐位）と培䧺液のエーテル或いは醋酸エ チル抽出物の電位と，該抽出物にヂペレリンAを添加 したものの電位とはそれぞれほぼ同一であつて，ヂへ レリンA，添加の回収萃は標淮波高に比し㤠んど 100\%

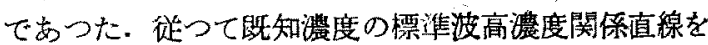
求め，その图表 (Fig. 3) に照らして未知試料の灌度 を測定することが出来る・尚この実験に用い大祫流計 の感度は $2.0 \times 10^{-10} \mathrm{~A} \mathrm{~mm}^{-1} \mathrm{~m}^{-1}$ であり, 電位の記 載はすぺて飽和甘承電極規準である. pH はガラス電 極を用いて測定した。

実 験 結 果

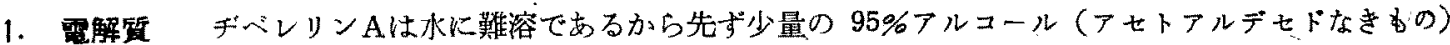
に溶解して水溶液とした，培盖液は酸性にてエーテル或いは醋酸エチルにて抽出し，これをヂベルレリンAと同 梯な方法で処理して水溶液とした，無関係塩としては KCl，KI 等無機塩類では還元洨を示さないので，有機電 解質である tetramethyl-ammomium bromide, chloride, iodide を用いたが，培盖液の有機溶剂抽出物中に 混在する他の有機酸の逥元波と分離する゙為に tetramethyl-ammonium bromide $\left(\mathrm{CH}_{3}\right)_{4} \mathrm{NBr}$ を用いることと した，ポーラログラフ法による定量の際温度は拡散電流即ち還元洨の波滈に及ぼす影響 ${ }^{(3)}$ が大であるので $20^{\circ} \pm$ 0.5 の恒温槽に電解瓶を入れて測定した.

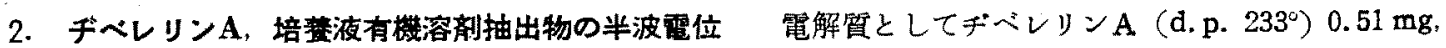

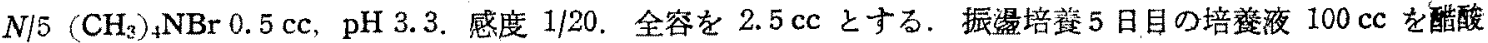
エチル 50 ずつにて 4 回抽出し, 抽出物を前述の如く処理して $10 \mathrm{cc}$ の水溶液とし，試料となすをその中から 
$2 \mathrm{cc}$ 採り $\mathrm{N} / 5\left(\mathrm{CH}_{3}\right)_{4} \mathrm{NBr} 0.5 \mathrm{cc}$ を加える. 全容 $2.5 \mathrm{cc}, \mathrm{pH} 3.3$.

次にギベレリンA（d.p. $233^{\circ}$ ) $0.522 \mathrm{mg}$ 前記抽出物の水溶液 $2 \mathrm{cck}$ に加光, $\mathrm{N} / 5\left(\mathrm{CH}_{3}\right)_{3} \mathrm{NBr} 0.5 \mathrm{cc}$, 全容 $2.5 \mathrm{cc} . \mathrm{pH}$ 3.3. 以上 3 つの試料につきボーラログラムを撮つた結果その還元波の半楛電位はいずれも一 $1.54 〜$

Table 1. Wave-Height and Half-Wave Potential of Gibb. $A$ and Culture Media.

$\begin{array}{lcccc}\text { Gibberellin A } & \begin{array}{c}\text { Wave-Height } \\ \mathbf{S = 1 / 2 0 \mathrm { mm }}\end{array} & \begin{array}{c}\text { Half-Wave } \\ \text { Potential } \\ \text { B } 2 \text { volt }\end{array} & \begin{array}{c}\text { Calcd. } \\ \text { Gibb. A } \\ \mathrm{mg} / \mathrm{cc}\end{array} & \begin{array}{c}\text { Found } \\ \text { Gibb. A } \\ \mathrm{mg} / \mathrm{cc}\end{array} \\ \begin{array}{c}\text { Broth } \\ \text { Gibberllin A }\end{array} & 15 & -1.56 & 0.204 & 0.200 \\ \quad+\text { Broth } & 32 & -1.57 & & 0.280 \\ \quad & & -1.54 & 0.208 & 0.500\end{array}$

1.57 volt (vs S.C.E.) である.

Table 1より gibberellin A の回 収率は $102.4 \%$ であつた。

3. ヂベレリン $\mathbf{A}$ の瀿度と波高と の関保 ヂベレリンAの逼元淓の定 量的に最策的な波形が得られるの

は $\mathrm{pH}$ 2.5〜6である.この $\mathrm{pH}$ 領域に於忛る鋠度と波高との関倸を Table 2, Fig. 3 に示す.

被僄元物の䉓解還元に於て波の高さ即方限界桩散電流 $I_{a}$ の大きさはILKovic 式(4)にて示される.

Table 2. Relation between the Concentration and the Wave-Height of Gibberellin A.

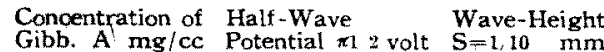

$\begin{array}{llll}1 & 0.075 & -1.52 . & 12 \\ 2 & 0.150 & -1.52 & 20 \\ 3 & 0.240 & -1.54 & 27 \\ 4 & 0.300 & -1.54 & 38 \\ 5 & 0.391 & -1.54 & 48 \\ 6 & 0.450 & -1.55 & 52 \\ 7 & 0.543 & -1.56 & 65 \\ 8 & 0.600 & -1.57 & 70\end{array}$

Table 3. Half-Wave Potential of the Substances except Gibb. A.

Substances

Gibberellin C

Gibberic acid

Gibb. A Methyl ester

(m. p. $225^{\circ}$ )

Gibb. A Methyl ester

(m. p. $190^{\circ}$ )

Dihydrogibberellin A

Fusaric acid

Fumaric acid

Oxalic acid

Succinic acid
Half-Wave

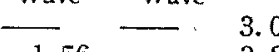

$-1.56-3.2$

$-1.06-6.1$

$-\quad 6.7$

$-1.06-6.5$

$-1.15-1.36 \quad 5.6$

$-0.81-3.3$

$-1.06-3.0$

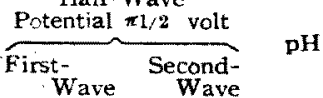

$-1.80-3.4$
$I_{d}=0.63 n F D^{1 / 2} \mathrm{Cm}^{2 / 3} t^{1 / 6}$

但し $C$ は被遥元物算の㗳度， $m$ は1秒間に流出する 水銀量， $t$ は水銀の谪下時間， $n$ は㟽元に関与する水 素原子或いは電子数， $F$ は Faraday， $D$ は搪散係数 である．故に同一物質を同じ電樰で電解する場合には $I_{d}=K C(K$ は比例恒数 $)$

であり，今の埸合には Fig. 3 に示した如く波高と濃 度とは直楾関保仙あり，定量可能である。ことに波高 を测定するに交点法を用いた。

4. ヂベレリンA以外の有機物の半波電位 ヂべ

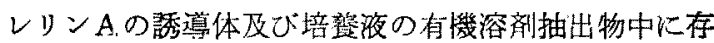
在するヂペレリンA以外の不純物と思われる有㙨酸の 還元波を椧した結果は Table 3 にて示寸。

\section{5. 這元波の高さと徒長試験による結果との比較}

证来著者等の行つて来た徒長試験 ${ }^{(5)}$ はデベレリンAの 生理学的特性として極めて重要な試験であつたが，被 検体としての稲の生育には温度，湿度，日照，水等種 種なる因子による影響が大きく，又粐の個体差による 徒長率の不均一等に上り，その生物試駼には測定時日 の長さと共に種種の困難を伴つた。ホーラログラフに

よる定量にはポーラログラム上の作図等の測定誤差はあるが，その迅速さに於て生物試験と比較にならない，著 者等は波高と生物試験による徒長率との関係を娭討したが，ポーラログラムによるヂベレリン量と淓高とは直線 関俰にあるも，生物試験によるヂベレリンの量と徒長率との関係はS字曲線であるので，必ずしも禹者は平行と は云点ない、ここに於てはただ波高と徒長率とを比較したにすぎない。

Table 4. Comparative Experiments of Abnormal Elongation Growth Test and Polarograph.

Days of Cultivation

* Abnormal Elongation $\mathrm{G}$ Growth Ratio \% As6

Wave-Height $\mathrm{S}=1 / 10 \mathrm{~mm}$

$\left\{\begin{array}{l}\mathrm{G} 4 \\ \mathrm{As6}\end{array}\right.$

$\begin{array}{rrrrrrrr}2 & 3 & 4 & 5 & 6 & 7 & 8 & 9 \\ 9 & 57 & 93 & 93 & 93 & 100 & 100 & 93 \\ 0 & 0 & 86 & 93 & 100 & 100 & 93 & - \\ 0 & 5 & 40 & 49 & 57 & 90 & 105 & 60 \\ 0 & 0 & 12 & 40 & 90 & 90 & 65 & -\end{array}$

振蕰培嶅 温度 $27^{\circ} \pm 0.5$, 日数 $8 \sim 9$ 日, 菌侎 $\mathrm{G} 4$, As6.

培荃条件, 徒長試験前報 (1) と同じ，各日培琶液 $200 \mathrm{cc}$ 醋酸エチルにて抽出，等分し て1つはボーラログラフ測定用

に，他は徒長試験（15日間）に供した，両者の比較を Table 4 に示寸。

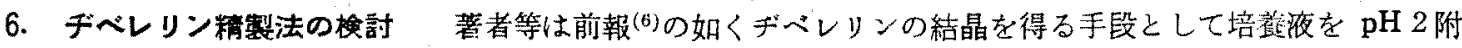
近で活性炭に吸着せしめアンモニア性メタノールで溶出したが，この方法にては収量に於てどの位の損失がある

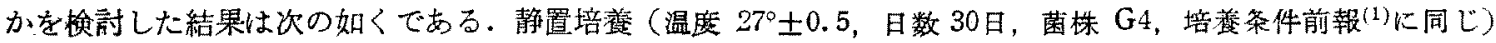




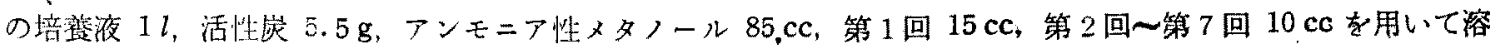

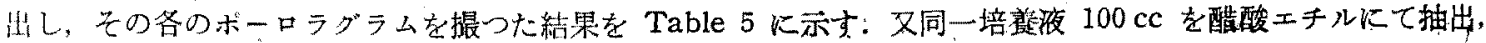

Table 5. Elusion Test of Gibberellin A.

$\begin{array}{cccccc} & \text { Sensitivity } & \begin{array}{c}\text { Wave-Height } \\ \text { nmm }\end{array} & \begin{array}{c}\text { Gibberellin A } \\ \text { /cc }\end{array} & \begin{array}{c}\text { Half-Wave } \\ \text { Potential } \pi 1 / 2 \text { volt }\end{array} & \% \text { of Recovery } \\ 1 & 1 / 100 & 39 & 310 & -1.54 & 51.6 \\ 2 & 1 / 100 & 27 & 190 & -1.52 & 30.6 \\ 3 & 1 / 30 & 10 & 25 & -1.52 & 0.8 \\ 4 & 1 / 20 & 5 & 10 & -1.51 & 0.3 \\ 5 & 1 / 10 & 5 & 10 & -1.51 & 0.1 \\ 6 & 1 / 10 & - & - & - & - \\ 7 & 1 / 10 & - & - & - & -\end{array}$

常法に従いポーラログラムを撮 つた処，波高 $71 \mathrm{~mm}$ を得， ペレリン量は標準波高濃度直線 より $6 \times 10^{3} \gamma$ であつた. Table 5 より培灙夜 $1 l$ 中に存在する ヂベレリン量は $50.8 \times 10^{3} \gamma$ な のでその回収率は $83.3 \%$ であ

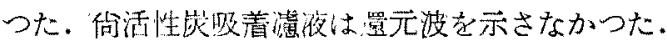

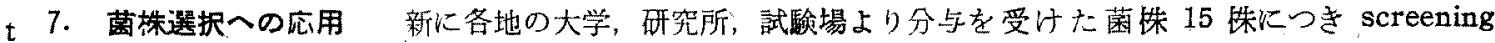
est を行つた結果，生物試験（15日）とポーラログラフ法に上る測定值とは Table 6 の如くである。ここに得

Table 6. Comparative Experiments of Abnormal Elongation Growth Test and Polarograph.

\begin{tabular}{|c|c|c|c|c|c|}
\hline Stens & $\begin{array}{l}\text { Abnormal } \\
\text { Elnngation } \\
\text { Growth } \\
\text { Ratio \% }\end{array}$ & $\begin{array}{l}\text { Wave- } \\
\text { Height } \\
\mathrm{S}=1 / 10 \\
\text { min }\end{array}$ & $\begin{array}{c}\text { Ha } \\
\text { Potent }\end{array}$ & $\begin{array}{l}\text { ff-Wave } \\
\text { ial } \pi l \& \text { volt }\end{array}$ & $\underset{\gamma / 10 c c}{\text { Gibberellin }} A$ \\
\hline $\mathrm{G} 4$ & 25 & 10 & & -1.47 & 60 \\
\hline As6 & 23 & 8 & & -1.48 & 40 \\
\hline No. 1 & - & 12 & $*$ & -1.30 & - \\
\hline $11 \quad 2$ & - & 16 & *. & -1.25 & - \\
\hline 1) 3 & - & 20 & * & -1.30 & - \\
\hline 114 & 20 & 11 & & -6.49 & 65 \\
\hline$\prime \prime$ & - & 5 & $*$ & -1.09 & - \\
\hline "1 6 & 12 & 6 & & -1.50 & 20 \\
\hline 117 & - & 30 & * & -1.04 & - \\
\hline 118 & - & 100 & * & -1.18 & - \\
\hline " 9 & - & 24 & $*$ & -1.09 & - \\
\hline $140-0$ & 17 & 10 & & -1.46 & 60 \\
\hline $140-1$ & 17 & 8 & & -1.45 & 40 \\
\hline $140-2$ & 17 & 7 & ; & $-1.09,-1.43$ & 30 \\
\hline $140-3$ & 13 & 5 & $*$ & -1.45 & 10 \\
\hline
\end{tabular}

* Half-Wave potential of the substances except Gibb. A
た傺良怢（No.4.140-0）を現 在静置培稂の菌株として用いて いる。収量の結果は未た報告す るに至つてない. Screening test として振湯培羑法を用い; 万法は前報(1)の如くである。

この表に於て半波電位－1.56volt 前後以外のbのはギベレ

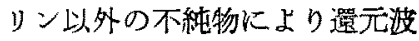
を示し，徒長淕験の結果は発芽 阻止した：

綜 括 (1) ヂベル酸の 吸収曲楾を測定し，その最大吸 収部波長 $265 \mathrm{~m} \mu$ の処で吸光保 数と濃度とはLAMBERT-BEER の法則に従い比例铮係を示すので，デベル酸をべックマン光電光度計により測定することが出来る．

(2) ヂベレリンAは有機電解質 $\left(\mathrm{CH}_{3}\right)_{+} \mathrm{NBr}$ の存在で還元波を示し，半波電位は - 1.56 volt (vs S.C.E.) である．波高と洮度とは比例関係を示すのでポーラログラフ法によりギベレリンAを定量することが出来る，

（3）堷趁液の有機溶㨈（エーテル，醋酸エチル等）抽出物の半波電位は上記ヂペレリンAと同一であり，ギ ベレリンAの添加回収率は殆んよ゙ $190 \%$ であつた。ポーラログラフ法により培養液中のヂベレリンAを定量する ことが出来る。

（4）ポーラログラフ法によりギペレリン多量生垭の為の条件を検討することが可能となつた。

終りにポーラログラフ法に上る測定に際し御便宜をはかつて下さつた 農林省農薬検査所，伊東技官，東大農学

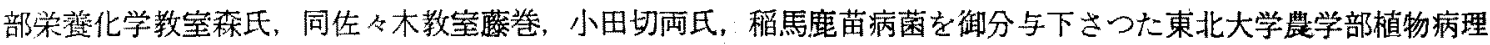
学教室, 北陸農業試験場，岡山大学大原研究所，農林省農薬検査所，日本特殊農薬䏭式会社に厚く感謝の意を表 する．伤本赛験は文部省科学研究費によつたものであることを附記する。

（1）北村，川原田，瀨田，高棍，大月，住木： 農化, 27, 545 (1953).

（2）荛田，住木，麻生，田村，五十嵐，玉利： 農化，17，897 (1941)

(3) 品川：ポーラログラフ分析法，62 (1952).
（4）石橋，藤永：分析化学の進步第 2 巻, 17 頁 (1943).

（5）掼田，住木，麻生，田村，五十嵐，王利： 豊化，17，724 (1941).

(6) 同上：同 $17,723(1941)$.

\section{Summery}

The bioassay using rice seed was the only method for the quantitative determination of gib- 
berellins. But this method is not so good, bacause not only it takes about 10 days but also the result is unreliable on account of the individuality of every seed. Therefore, it is hoped that some physico-chemical methods should be found as soon as possible. For this reason, this experiment was undertaken and the following results. were obtained. The authors consider the polarographic method under described is very useful for studies of gibberellins, such as the studies on the medium composition, preparing process and mode of action in living cell.

1) We found that the relation between the extinction coefficient and the concentration of gibberic acid was proportional satisfying LAMEERT-BEER's law, and therefore gibberic acid could be determined quantitativeiy by the spectrophotometric measurement. (Fig. 1)

2) We found that gibberellin A gave a reduction wave. In a $0.5 \times 10^{-3} . M$ solution of this substance, when $0.04 \mathrm{~N}$ tetra-methylammonium bromide being used as a supporting electrolyte, the half-wave potential was -1.56 volt (vs. S.C.E.) as shown in Fig. 2 . As the relation of the wave-heights of gibberellin A to its concentration was found to be proportional linearly, gibberellin A could be determined quatitatively by means of the polarographic method. (Fig. 3 )

3) Except gibberellin $\mathrm{A}$ and gibberic acid, the acids such as gibberellin $\mathrm{C}$, fusaric, succinic, fumaric and oxalic acids gave the other reduction potentials. From this fact it was found that gibberellin $\mathrm{A}$ in the medium could be determined quantitatively and, moreover; its accuracy was indorsed from the result of bioassay which was carried out as the comparison, at the same time.

\section{所謂內地米及び外地米の溉粉について（第3 報） 陸羽 132 号米澱粉について}

福場博俣, 山本フジ子（㨲の水女子大学栄着化学教室）

昭和 99 卧 2 月 17 日受理

Starches of Oryza sativa L. japonica and Oryza sativa L. indica. Part 3.

Rikuu No. 132 Rice Starch.

By Hiroyasu Fuxuba and Fujiko Yamamoto

(Lab. of Nutritional Chemistry, Ochanomizu Univ.)

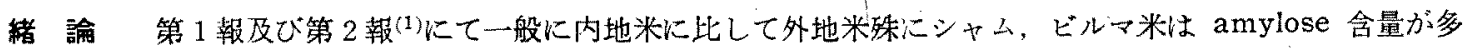

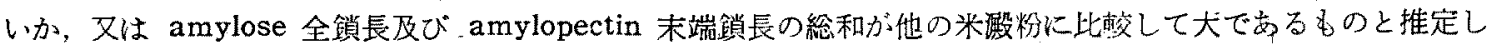
た。この推定を出すに用いた実験方法としてはヨード電圧滴定法，ヨード反応比色法， B-amylase による糖化 率の測定及び BRABENDER の amylogram t用いた。

各種米粉の BRABENDER àmylogram をとつてみると糯米が最も BRAEENDER unit (粘度単位) が低く， 外地米殊にシャム米が最高値を示し，内地粳米汀度而者の中間値を示した。この事は本装置を用いて粘度測定 をする時には $25^{\circ} よ り 1$ 分間 $1.5^{\circ}$ つつ 45 分間温度上昇させ，更に 45 分間迹に 1 分間 $1.5^{\circ}$ つ冷却して $25^{\circ}$

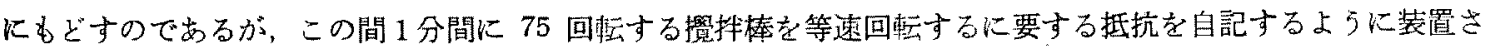
れてある為に線状分子である amylose の多い澱粉程分子と分子とのからみ合いが激しくなり，その為に BRA. BENDER unit は上型するが, 球状構造をとる amylopectin 含量の多い精米ではこのからみ合いが少い為に BRABENDER unitは上算しないるのと推論した。

この点について実際に amylose 及び amylopectin を分灕し，この両者の amylograms を求めて以上の推 諭の正否を確かめてみた，夺前報にて陸羽 132 号澱粉が特殊な反灾を示し，恐らく amylose と amylopectin の中間型である末端鎖長の著しく長い amylopectin を多く含も澱粉であろうと推定した。この点にやいても， このような中間型の性筧を確める為に二，三の実験を行めたので報告する.

\section{実験 $の$ 部}

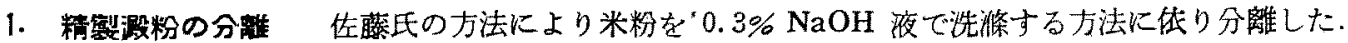

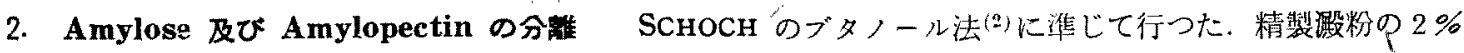
液を作り加熱糊化した後，この糊化液 $1 l$ 当り $100 \mathrm{ml}$ の nーブタノールを加え $\mathrm{pH} 6.8$ に調整した後 auto 